Int. J. Electrochem. Sci., 14 (2019) $8557-8568$

\title{
Electrolytic Refining of High Carbon Ferrochromium to Produce Pure Ferrochromium in NaCl-KCl Melt
}

\author{
Qian Kou ${ }^{1,2}$, Weiliang Jin ${ }^{1,2}$, Guolong Liu ${ }^{1,2}$, Meichen Wang ${ }^{1}$, Saijun Xiao ${ }^{1,2, *}$ \\ ${ }^{1}$ School of Metallurgy Engineering, Anhui University of Technology, Maanshan, Anhui, China, \\ 243002; \\ ${ }^{2}$ Key Laboratory of Metallurgical Emission Reduction \& Resources Recycling, Anhui University of \\ Technology, Maanshan, Anhui, China, 243002. \\ *E-mail: jxddroc@126.com
}

doi: $10.20964 / 2019.09 .05$

Received: 13 April 2019 / Accepted: 20 June 2019 / Published: 31 July 2019

\begin{abstract}
In this paper the electrolytic refining of remelted high carbon ferrochromium ( $\mathrm{HCCrFe}$ ) to produce pure ferrochromium in molten salts was investigated. The remelted $\mathrm{HCCrFe}$ was employed as the working electrode, tungsten as the counter electrode, and $\mathrm{Ag} / \mathrm{AgCl}$ as the reference electrode, to establish a threeelectrode cell. Potentiostatic electrolysis (anode potential, $0.3 \mathrm{~V}$ vs $\mathrm{Ag} / \mathrm{AgCl}$ ) was conducted in $\mathrm{NaCl}$ $\mathrm{KCl}$ melt at a temperature of $710^{\circ} \mathrm{C}$. The cathode product was examined by x-ray diffraction (XRD), elemental analysis and $\mathrm{x}$-ray photoemission spectroscopy (XPS). The results indicate that pure ferrochromium with low contents of $\mathrm{C}, \mathrm{S}$, and $\mathrm{P}$ has been successfully prepared by this method. In addition, the left anode residue was also characterized by scanning electron microscopy (SEM) and energy disperse spectrum (EDS), exhibiting porous appearance with a large amount of carbon contained. Subsequently, galvanostatic electrolysis was performed with different current densities $\left(0.33 \mathrm{~A} \cdot \mathrm{cm}^{-2}\right.$, $0.50 \mathrm{~A} \cdot \mathrm{cm}^{-2}, 0.58 \mathrm{~A} \cdot \mathrm{cm}^{-2}$ and $\left.0.66 \mathrm{~A} \cdot \mathrm{cm}^{-2}\right)$. The composition and microstructure of the deposited ferrochromium under these different conditions were analyzed by XRD and SEM. It is found that with the increase of current densities, the particle size of cathode product becomes coarser and tends not to be oxidized.
\end{abstract}

Keywords: high carbon ferrochromium, pure ferrochromium, electrolytic refining, molten salts

\section{FULL TEXT}

(C) 2019 The Authors. Published by ESG (www.electrochemsci.org). This article is an open access article distributed under the terms and conditions of the Creative Commons Attribution license (http://creativecommons.org/licenses/by/4.0/). 